\title{
Use of Reporter Genes in the Generation of Vaccinia Virus-Derived Vectors
}

\author{
Sally Al Ali ${ }^{\dagger}$, Sara Baldanta ${ }^{\dagger}$, Mercedes Fernández-Escobar and Susana Guerra * \\ Department of Preventive Medicine, Public Health and Microbiology, Universidad Autónoma, E-28029 Madrid, \\ Spain; sally.alali@yahoo.com (S.A.A.); sara.baldanta@uam.es (S.B.); mercedes.fernandeze@uam.es (M.F.-E.) \\ * Correspondence: susana.guerra@uam.es; Tel.: +34-91-497-5440 \\ + These authors contributed equally to this work.
}

Academic Editor: Luis Martinez-Sobrido

Received: 18 March 2016; Accepted: 12 May 2016; Published: 21 May 2016

\begin{abstract}
Vaccinia virus (VACV) is one of the most extensively-studied viruses of the Poxviridae family. It is easy to genetically modify, so it has become a key tool for many applications. In this context, reporter genes facilitate the study of the role of foreign genes introduced into the genome of VACV. In this review, we describe the type of reporter genes that have been used to generate reporter-expressing VACV and the applications of the recombinant viruses obtained. Reporter-expressing VACV are currently employed in basic and immunology research, in the development of vaccines and cancer treatment.
\end{abstract}

Keywords: vaccinia virus; vaccine; reporter-expressing virus

\section{Introduction}

Since the first description of recombinant DNA techniques, many advances have been achieved in the field of molecular biology and genetic modification. Currently, there is a wide variety of tools that allow the genetic modification of animals, plants, bacteria and viruses [1-4]. The genetic modification of viruses has become one of the best strategies for introducing nucleic acids into different cells, tissues or even in in vivo models, given the high transfection efficiency and ease of carrying it out, compared to chemical or physiological methods [5,6].

After the description of recombination events in cells infected with vaccinia virus (VACV) and through recombinant DNA technology [7,8], VACV has become a suitable model for the generation of recombinant virus vectors [9]. At first, the main purpose for introducing foreign genes into virus genomes was basic research about the biology of the viruses both in vitro and in vivo. However, with the latest technical advances and the higher understanding of the VACV viral cycle, virus genetic modification is getting a wider spectrum purpose. Thus, they can also be used for the development of vaccines or as oncolytic agents. This review aims to highlight the main aspects of the genetic modification of VACV and the generation and application of reporter-expressing virus in this model.

\section{Biology of VACV}

VACV is the prototype member of the Poxviridae family, so most research of poxvirus has been focused on its use [10]. VACV is a large DNA double-stranded virus, with a complex envelope. It was the live vaccine used to eradicate smallpox and nowadays is also used as a viral vector for recombinant vaccines and cancer therapy $[9,11]$. The VACV genome is one of the largest of all DNA viruses, with a size of $190 \mathrm{kbp}$ and about 250 encoding genes [12]. The genome has a high genetic compaction, with a few intergenic and small non-coding regions. The coding regions are continuous, thereby not given to splicing $[13,14]$. 
VACV have a complete replicating cycle inside the cytoplasm of the host cell, even though it is a DNA virus (Figure 1) [10]. This fact determines the genetic characteristics of the virus, being completely independent of the replication and transcription machinery of the host cell. Once the virion infects the host cell, the viral core is uncoated, and nearly 100 early viral genes are transcribed $[15,16]$. Early genes produce the required enzymes for catalyzing the viral core breakdown, viral DNA replication and the modulation of the host antiviral response [17]. Viral DNA begins to replicate inside the infected host cell using viral enzymes at $3 \mathrm{~h}$ post-infection. As soon as the viral replication starts, transcription of downstream genes encoding for regulatory proteins that induce the expression of the late genes occurs. Late genes encode for proteins and enzymes required for the assembly of new viral particles. After DNA and all viral proteins are synthesized, the process known as morphogenesis begins, which results in the formation of the new virions $[18,19]$. These can be retained inside the cell until cellular lysis or released to the environment by other mechanism $[10,18]$.

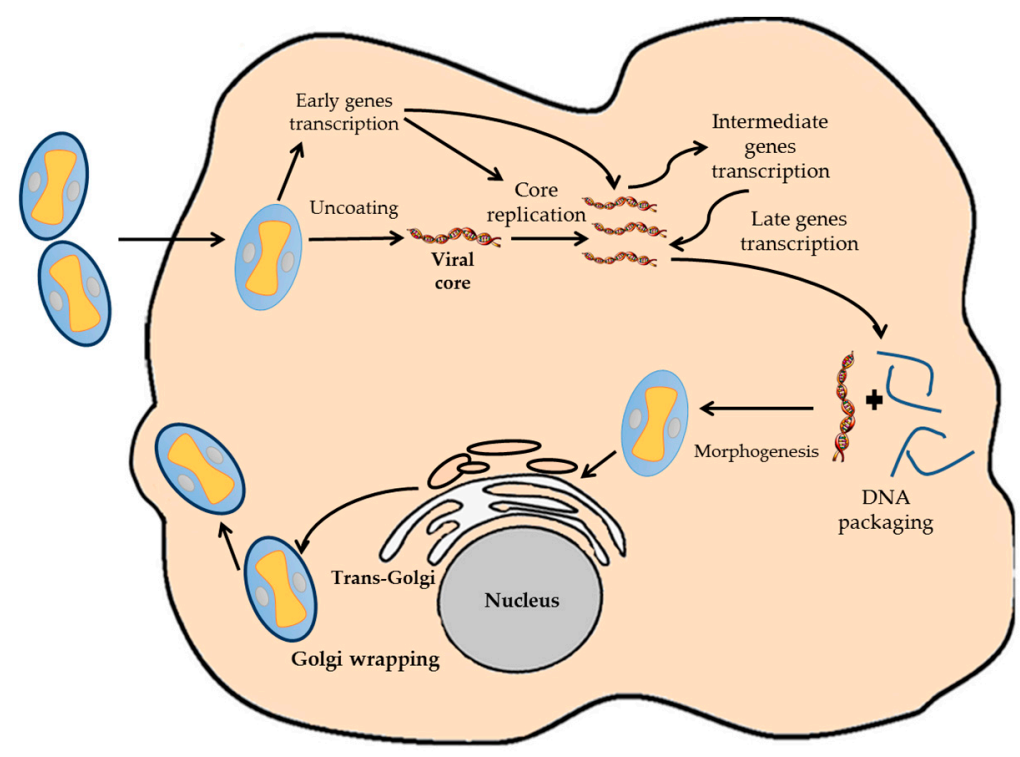

Figure 1. Diagram representative of the VACV infection cycle. The different steps of the VACV cycle are indicated.

\section{VACV as a Vector}

Several features of the biology of VACV make it suitable for its use as a vector in biological experiments, vaccine design or cancer therapy. The complete cytoplasmic replication of VACV facilitates the expression of foreign genes inserted in the viral genome and its detection or isolation [20,21]. Usually, bacterial or non-mammalian viral vectors fail to make the expressed proteins to perform its full activity as antigens. However, VACV has the ability to transcribe its genes using its own transcription factors and enzymes. That means that if a foreign gene is inserted directly to a VACV promoter element, it will be transcribed with foreign proteins reaching high levels of expression in the infected cell. Moreover, this replication cycle is an appropriate model for molecular and genetic investigations of cis and trans factors that are mainly required for gene expression [12,22]. Furthermore, since VACV remains in the cytoplasm, the risk of insertional mutagenesis and oncogenesis, the main problems encountered in gene therapy using integrative viruses, disappears. In some cases, patients treated with retroviral vectors have developed cancer years after they have been treated $[5,23]$.

VACV can replicate in different cell lines, primary cell cultures, and also grows in several animal species, such as mice, guinea pigs, rabbits, etc. [10]. This broad host range allows infection of cell lines with recombinant viruses for large-scale expression of heterologous proteins, which reduces its cost in comparison to other production systems [21,24]. Additionally, VACV enables high production titers, so it is an advantage in the manufacturing of a large amount of vaccines [6]. 
Although the VACV genome is large and compact, it can tolerate the deletion of certain viral sequences and the insertion of exogenous genetic material [25]. A VACV vector has a transgene capacity of approximately $25-30 \mathrm{~kb}$, higher than other viral vectors, including adeno-associated virus $(4.5 \mathrm{~kb})$, adenovirus $(8-10 \mathrm{~kb})$ and retrovirus $(7-8 \mathrm{~kb})$ [4]. Thus, VACV is an excellent candidate vector in the design of polyvalent vaccines with antigens from several pathogens or different antigens from the same pathogen $[9,26]$.

Finally, as far as its use as a vaccine vector is concerned, VACV is clearly immunogenic effective, strong evidence being the eradication of smallpox in 1980 [11]. VACV is also safe and easy to inoculate, since it can be administrated intradermally or with an air gun without medical training. In some organisms, it has been found that it can cause problems by preexisting immunity, but the probability of having post-vaccination complications, such as progressive VACV infection or encephalitis, is significantly low[27]. Nowadays, due to the better knowledge of the VACV biology and the immune response generated after vaccination, vaccines based on this virus are becoming safer [9]. In addition, it is important to remark that VACV vectors are very stable and can be lyophilized and kept frozen for several years, facilitating its transport and storage [23].

\section{Design Considerations in the Generation of VACV Vectors}

To get recombinant VACV expressing foreign genes, the main method used is homologous recombination (Figure 2) [28]. First, it is necessary to construct a plasmid that contains the gene or transgene of interest. After that, the cells have to be infected with the virus and subsequently transfected with the plasmid that contains the transgene. An alternative method could be used, employing two viruses, one defective for some genes and one wild-type acting as a helper [4,29]. For both methods, the recombinant viruses are produced by homologous recombination inside the infected cell.

\section{Wild-type VACV}

\section{Insertion vector}
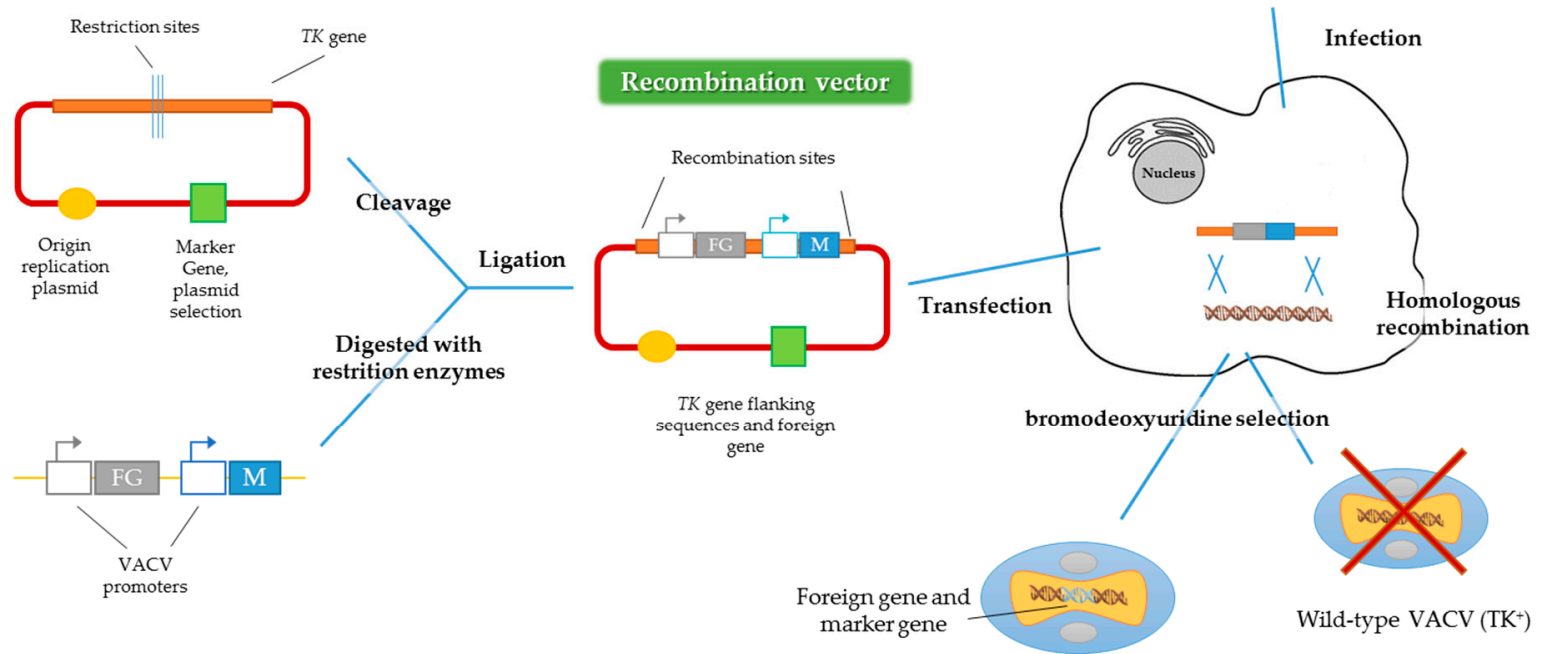

TK- recombinant virus

Figure 2. Construction of recombinant VACV vectors by homologous recombination. FG represents the foreign gene and $\mathrm{M}$ represents the marker gene and TK: thymidine kinase gene. Adapted from [28].

Another way to generate recombinant viruses is the method described by Falkner and Moss [30], denominated transient dominant selection (TDS), which allows the introduction of site-directed 
mutations into the VACV genome. Generally, the recombinant viruses obtained by this method are rescued by metabolic selection, using the guanine phosphoribosyltransferase gene (gpt) from Escherichia coli as a marker. The presence of the protein encoded by gpt allows the recombinant viruses to grow in the presence of mycophenolic acid, xanthine and hypoxanthine [31]. Subsequently, after this first metabolic selection, a second recombination event must occur to eliminate the selection marker, maintaining the mutation introduced into the VACV genome (Figure 3) [32]. In contrast to the method described above, in the TDS technique the marker should not be flanked by homologous regions of the VACV genome [30]. Alternatively, puromycin resistance could be used as a selection marker in TDS, increasing the recombinant viruses' generation efficiency [33].

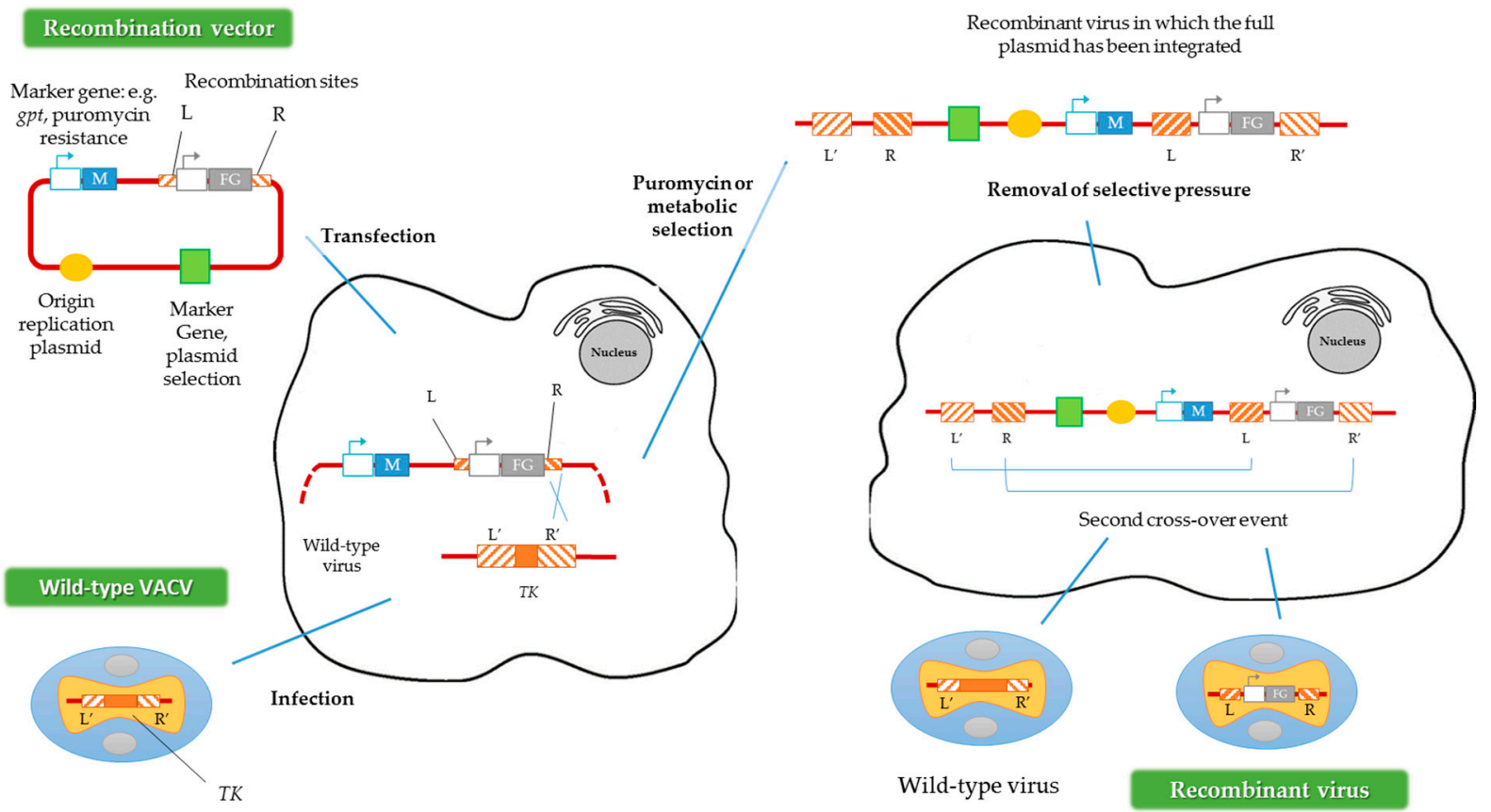

Figure 3. Construction of recombinant VACV vectors by the transient dominant selection (TDS) technique. FG represents the foreign gene and $\mathrm{M}$ represents the marker gene. $\mathrm{R}$ and $\mathrm{L}$ represent the right and left flanking regions of the TK gene in the plasmid, and $\mathrm{R}^{\prime}$ and $\mathrm{L}^{\prime}$ represent the same regions of the TK gene in the VACV genome. Adapted from [33].

Two important aspects to be considered when obtaining recombinant poxvirus are the VACV genome insertion sites and the reporter genes introduced.

\subsection{VACV Genome Insertion Sites}

The VACV genome has about seven known insertion sites where foreign genes can be inserted (Figure 4) [13]. The insertion site choice depends mainly on the future application of the recombinant viruses. It may also be important in the later selection of the recombinant viruses obtained. For instance, inserting the gene of interest in the thymidine kinase (TK) locus confers a detectable phenotype (TK-): the recombinant viruses are able to grow in the presence of 5-bromo-2'-deoxyuridine (BrdU), a synthetic analog of thymidine $[28,34]$. Another important site of insertion that allows a subsequent selection is the VACV hemagglutinin ( $H A$ ) gene as the recombinant viruses can be easily recognized by their disability to bind erythrocytes in a hemagglutination test [35-37].

VACV has five more places of insertion: the BamHI site of the HindIII-F DNA fragment [38]; the VACV growth factor gene (VGF), located in both inverted terminal repeats (ITRs) [39]; the N2 and M1 genes located on the left side of the VACV genome [40]; the M1 subunit of the ribonucleotide reductase $(R R)$ gene in the HindIII-I DNA fragment [41]; and the A27L gene encoding the $14 \mathrm{kDa}$ fusion protein, in the large HindIII-A DNA fragment [42]. It is noteworthy that some strains of VACV have only one 
copy of VFG, such as VACV Lister variants [33]. Recombinant production using these insertion sites, although successfully occurring, requires the use of a marker gene or other strategies for later selection of the recombinant viruses. Due to these limitations, the TK gene is the most common site of insertion in the VACV genome [5]. Some authors have used temperature-sensitive VACV strains, allowing the recombinant viruses to be selected in culture at $40^{\circ} \mathrm{C}$ [43]. However, the most common way for an easy identification of recombinant viruses is the use of reporter genes as selectable markers, which will be discussed in Section 4.2 [44].

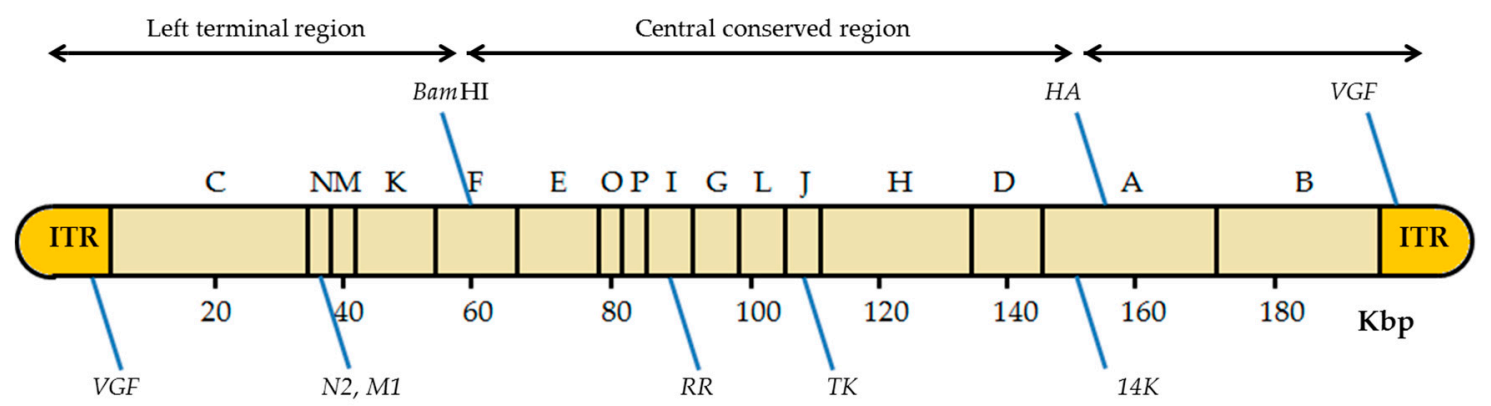

Figure 4. Scheme of the insertion sites in the VACV genome. The diagram of the VACV genome with the HindIII restriction sites is shown, including the location of the different insertion sites. BamHI: BamHI site of the HindIII F fragment; HA: hemagglutinin gene; VGF: VACV growth factor gene; N2: N2 gene; M1: M1 gene encodes the large subunit of ribonucleotide reductase (RR); TK: thymidine kinase gene; $A 27 \mathrm{~L}$ : gene that encodes the $14 \mathrm{kDa}$ fusion protein; ITRs: inverted terminal repeats. Adapted from [13].

In spite of the promoter or the regions between the promoter and coding region, the insertion site also influences foreign gene expression and virus virulence $[13,23,25]$. Insertion into the $T K, V G F, R R$ or $A 27 \mathrm{~L}$ genes has an impact on viral replication in vivo, but not in vitro [25,45]. Moreover, the method described in Figure 2 requires the use of special cell lines or mutagenic selective agents, such as TK-/cell lines and BrdU [30]. For this reason, different strategies and new insertion sites are being studied to ensure the correct expression of the transgenes in vitro and in vivo [25,33,46,47].

\subsection{Reporter-Expressing Viruses}

Reporter-expressing viruses are recombinant viruses expressing a reporter gene [48]. In some cases, the reporter gene is located downstream of a viral promoter, to study biological pathways or, fused with other viral or foreign genes. As reporter genes are expected to be easily detected, they are the best indicators for screening successfully recombinant viruses. The reporter gene should be chosen considering the non-endogenous activity in the cell type, tissue or organism used to culture the viruses [44]. Reporter genes have additional applications in vitro and in vivo, as the reporter gene acts as a substitute of the gene of interest. Moreover, reporter genes facilitate the use of tissue-specific and pathway-specific promoters, as well as regulatory promoter elements as biomarkers for a particular event route. Furthermore, it is important that the existence of the reporter gene should not affect the normal physiology and general characteristics of the transfected cells [48-50]. Table 1 presents an overview of the reporter genes commonly used in the generation of recombinant VACV. 
Table 1. Reporter genes commonly used in the generation of recombinant vaccinia virus (VACV).

\begin{tabular}{ccccc}
\hline Reporter Gene & Origin & Product & Detection & Reference \\
\hline CAT & Escherichia coli & $\begin{array}{c}\text { Chloramphenicol } \\
\text { acetyltransferase }\end{array}$ & $\begin{array}{c}\text { Thin-layer chromatography } \\
\text { autoradiography, ELISA }\end{array}$ & {$[51,52]$} \\
\hline LacZ & Escherichia coli & $\beta$-galactosidase & Colorimetry & {$[53]$} \\
\hline GUS & Escherichia coli & $\beta$-glucuronidase & Colorimetry or fluorescence & {$[54]$} \\
\hline GFP & $\begin{array}{c}\text { Aequorea victoria } \\
\text { (jellyfish) }\end{array}$ & Green fluorescent protein & Fluorescence & {$[50,55]$} \\
\hline LUC or lux CDABE & $\begin{array}{c}\text { Photinus pyralis (firefly) } \\
\text { and bacteria }\end{array}$ & Luciferase & Luminescence & {$[56,57]$} \\
\hline
\end{tabular}

ELISA: enzyme-linked immunosorbent assay.

\subsubsection{Chloramphenicol Acetyltransferase}

CAT was the first reporter gene used in transcriptional assays in mammalian cells. CAT is an enzyme from Escherichia coli that detoxifies the antibiotic chloramphenicol, which inhibits protein synthesis in bacteria [58]. Particularly, CAT links acetyl-coenzyme A (acetyl-CoA) groups to chloramphenicol, preventing it from blocking the $50 \mathrm{~S}$ ribosomal subunit. This gene is not found in eukaryotes, so eukaryotic cells do not present any basal CAT activity [44]. The reaction catalyzed by CAT can be quantified using fluorogenic or radiolabeled substrates, such as ${ }^{3} \mathrm{H}-$-labeled acetyl-CoA and ${ }^{14} \mathrm{C}$-labeled chloramphenicol. CAT can be detected either by thin-layer chromatography, autoradiography or enzyme-linked immunosorbent assay (ELISA) [51].

There is a strong link between $C A T$ gene transcript levels and enzymatic activity, which is easy to quantify. Thus, CAT has become a suitable reporter gene for investigating transcriptional elements in a wide variety of experiments implicating animal and plant cells, as well as viruses [51]. There are some disadvantages of using the CAT system, such as the higher amount of cells required when compared to other assays, like the luciferase assay (detailed in Section 4.2.5). In addition, the CAT system is not suitable for use with weakly-expressed genes and $C A T$ promoter activity quantification takes longer than other reporter systems [52]. Finally, this reporter gene has another important limitation due to the use of radioisotopes [44].

\subsection{2. $\beta$-Galactosidase}

The first study using lacZ as a reporter gene was published in 1980, and since then, it has become one of the most commonly-used reporter genes in molecular biology [49]. Although $\beta$-galactosidase catalyzes the cleavage of the disaccharide lactose to form glucose and galactose, it recognizes several artificial substrates, which has promoted its use as a reporter gene [58]. Thus, $\beta$-galactosidase can hydrolyze substrates such as ortho-nitrophenyl beta-galactoside (ONPG), 5-bromo-4-chloro-3-indolyl beta-D-galactopyranoside (X-Gal) and 3,4-cyclohexenoesculetin beta-D-galactopyranoside (S-Gal), resulting in a yellow, blue or black product precipitate, respectively [53,59]. Furthermore, expression of the lacZ gene can be stimulated with isopropyl beta-D-thiogalactopyranoside (IPTG), which is a highly stable synthetic and non-hydrolyzable analog of lactose [49].

One of the applications of the lac $Z$ reporter gene is the selection of transformed bacterial colonies. The recombinant (white) and non-recombinant (blue) bacteria are discriminated based on the interruption of the lacZ gene by the insert DNA or gene of interest using X-Gal as a substrate [53]. Other uses are the visualization of the $\beta$-galactosidase expression in transfected eukaryotic cells or the selection of the recombinant virus by viral plaque screening [60]. Finally, lac $Z$ is used to detect $\beta$-galactosidase activity in immunological and histochemical experiments [44]. One of the main advantages of using this reporter gene system is its low cost, since it does not require specific devices to detect the colorimetric reaction or to identify its expression. 


\subsection{3. $\beta$-Glucuronidase}

Another Escherichia coli-derived hydrolyzing enzyme gene that lends a reporter assay is GUS. The $\beta$-glucuronidase protein catalyzes the breakdown of complex carbohydrates, such as glycosaminoglycans. This reporter gene system has been widely used in transgenic plants, and it has also been successfully used in mammalian cells for VACV recombinant virus selection [54]. For the $\beta$-glucuronidase (GUS) assay 4-methylumbelliferyl beta-D-glucuronide (MUG) or 5-bromo-4-chloro-3-indolyl beta-D-glucuronide (X-Gluc) can be used as substrates. They respectively lead to a fluorogenic or a blue product after cleavage [61,62]. Monitoring $\beta$-glucuronidase activity through a GUS assay allows the determination of the spatial and temporal expression of the gene of interest [63].

\subsubsection{Florescent Proteins}

The most known fluorescent protein is green fluorescent protein (GFP), which was cloned from the species of jellyfish Aequorea victoria. Because of the great impact of fluorescent proteins in molecular biology applications, the Nobel Prize in Chemistry 2008 was awarded to Osamu Shimomura, Martin Chalfie and Roger Y. Tsien for the discovery and development of GFP [64,65]. GFP is the most used reporter gene; however, genetic engineering has developed a wide variety of color mutants, such as red fluorescent protein (RFP) or yellow fluorescent protein (YFP) among others [49].

Fluorescent proteins tolerate $\mathrm{N}$ - and C-terminal fusions to a wide-range of proteins, have been expressed in most known cell types and are used as a non-harmful fluorescent marker in living cells and organisms. The use of fluorescent proteins allows a variety of applications: cell lineage tracker , reporter for gene expression assays or measure of protein-protein interactions. Additionally, cell-fixation is not needed to examine its expression, and the probability of artifacts is quite small compared to immunocytochemical methods which require cell fixation [44]. One of the disadvantages of these proteins is their size. Therefore, in some cases, they can affect the in vivo function of fused proteins or genes of interest. Nevertheless, one limitation of using GFP is its low sensitivity [66], another is that its signal cannot be exogenously amplified [50].

\subsubsection{Luciferases}

The first luciferase (LUC), from the firefly Photinus pyralis, was cloned in 1980 and LUC has been widely used as a reporter gene. Later, it was also described in bacteria and dinoflagellates [44]. Luciferases are enzymes that catalyze a chemical reaction resulting in the production of light. Firefly luciferase oxidize the D-luciferin, in the presence of oxygen and adenosine triphosphate (ATP) as the energy source. As in $\beta$-Galactosidase assays, an exogenous substrate is needed, and it may be a disadvantage [49]. In other systems, such as the luciferase identified in bacteria (luxCDABE operon), the enzyme catalyzes the oxidation of long-chain aldehydes and flavin mononucleotides $\left(\mathrm{FMNH}_{2}\right)$ in the presence of oxygen to yield green-blue light [67]. Although in bacteria this operon encodes all components necessary for light emission, it is limited in mammalian cells. Therefore, the exogenous substrate has to be added to improve the reaction [56]. Besides the different substrates required, each luciferase system is categorized by having specific kinetics, with a particular detection and sensitivities that require adjusting the experimental design $[58,67]$.

The use of luciferase is extremely widespread in biological systems studies and includes cell proliferation assays, protein folding/secretion analyses, in vivo imaging and control of in vivo viral spreading [57,67-69]. The main advantage of using this system is its high sensitivity when compared to other systems, such as CAT. Additionally, the LUC system is more direct, rapid and suitable when it comes to weakly-expressed genes, and it can be used to quantify gene activity. One disadvantage of the LUC system is the requirement of ultrasensitive charge-coupled device (CCD) cameras to detect gene expression [56]. 


\section{Applications of Reporter-Expressing Viruses}

\subsection{In Vitro Applications}

Reporter-gene assays have helped the pox virologists in basic research, for example for the study of the location, structure and function of many VACV proteins during the infection cycle and their interaction with proteins of the host cell [44,70]. As shown in Dvoracek and Shors [63], the GUS reporter gene was used for deleting the D9R viral protein and selecting the recombinant viruses, with the aim to understand the role of this protein in the viral life cycle. In addition, the lacZ gene has typically been used mainly for the selection of recombinants [71]. Moreover, several studies have reported the different transgenes' insertion points and VACV promoters in which the recombinant virus production was enhanced. These studies are essential for improvement of the development of vaccines based on recombinant VACV [62,72].

On the other hand, fluorescent markers such as the GFP, YFP or luciferase are also useful for labelling VACV replicative strains. These viruses have allowed the study of processes like the input and output morphogenesis in virus-infected cells $[68,69,73-76]$. In these studies, fluorescence of certain viral proteins allows us to study their interaction with other viral or cellular proteins [77]. Furthermore, VACV is a clear example of how viruses have developed strategies to evade the immune response [78]. In this field, the generation of recombinant VACV with reporter genes is also useful to discern the molecular mechanism by which VACV proteins manipulate the immune system of the host. Thus, in Unterholzner et al. [79], the generation of a GFP-labeled recombinant VACV revealed that the C6 viral protein acted as an immunomodulatory agent, blocking the expression of type I interferon.

Another major application of reporter-expressing VACVs is the design of high-throughput assays. The generation of lacZ or GFP expressing recombinant virus can be used to optimize antibody neutralization assays $[71,80]$.

Lastly, VACV and reporter genes have been used to study proteins from other viruses, particularly RNA viruses, such as influenza or severe acute respiratory syndrome-associated coronavirus (SARS-CoV) [81]. To genetically modify these viruses, RNA must be reverse transcribed to cDNA, since this is particularly unstable in plasmids, making VACV a good tool for functional studies of proteins from such viruses [82].

\subsection{In Vivo Applications}

There are several in vivo applications for recombinant reporter-expressing viruses. For example, in virulence studies, the use of labeled viruses allows us to follow the viral pathogenicity and detect in which organs the viral replication and dissemination occur [70,76]. For example, Zaitseva et al. [69] used the recombinant VACV Western Reverse strain (WR)-LUC to analyze the viral spread in vivo for several days reducing the number of mice used. Moreover, VACV is an effective enhancer for both humoral and cell-mediated immunity; it is used as a vector to study the immune system and the expression of proteins' antigenicity of other pathogens. Furthermore, VACV is used to explore the immunopathological mechanisms, to know which epitopes or antigens presented by a pathogen have the ability to induce the host-immune response, and to demonstrate the specific role of a particular antigen during the pathogenic process $[13,83,84]$.

Despite the examples mentioned above, the most common uses of recombinant VACV in vivo are the production of prophylactic vaccines and treatments against cancer $[4,85]$. Table 2 shows some of the vaccines based on VACV, with the reporter gene and the insertion site employed indicated in each case. In these vaccines, VACV acts as a vector capable of delivering antigens from other organisms [23]. While in many recombinant vaccines a viral antigen has been inserted, some of them have also been developed against bacteria $[86]$ or protists $[34,87,88]$. These vaccines simulate infection by the pathogen from which the antigens are and elicit the immune response, by producing antigens for different pathogens. In several vaccines, mainly against human immunodeficiency virus (HIV) or influenza, genes of immunomodulatory cytokines are added for coexpression with the antigen, 
improving the immunogenicity of the vaccines $[23,89,90]$. As summarized in Table 2 , most of the transgene insertion sites are within the $T K$ or the $H A$ genes, making the selection of recombinants easier, as explained above. However, in several vaccines, besides using this strategy, a reporter gene is used as well. The use of reporter genes facilitates the preliminary tests of the vaccine on animal models. Moreover, especially in vaccines used in animals, the reporter gene makes it possible to distinguish between vaccinated and infected animals [48]. For example, VACV has been used for nearly twenty years to eradicate rabies from wildlife as an oral-based vaccine. In this case, the recombinant VACV expresses the rabies virus glycoprotein and has been used to vaccinate raccoons, red foxes, skunks and coyotes in the United States and Europe. This battle has successfully purged rabies in some parts of Europe and the United States [91].

Table 2. VACV-derived vaccines.

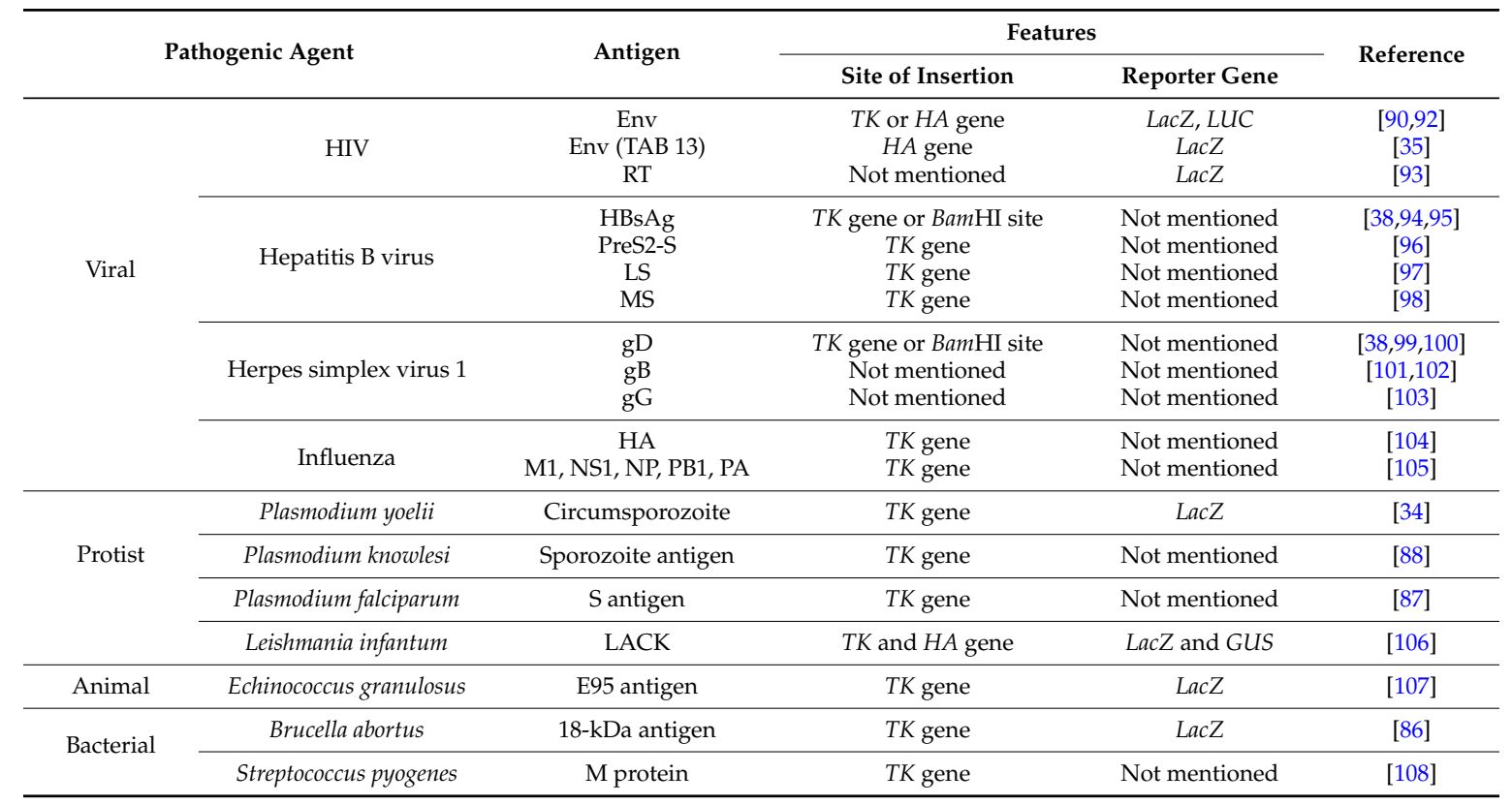

Another application for VACV vectors is in cancer treatment, known as oncolytic virotherapy [26]. This is the use of replication-competent viruses to selectively attack and destroy cancer cells, without harming healthy host cells [109]. Examples of recombinant VACV used are summarized in Table 3. A promising study is the use of oncolytic VACV as a vector for the human sodium iodide symporter ( $h N I S)$ gene in prostate cancer therapy, which has been demonstrated to restrict tumor growth and to increase survival in mice [110]. VACV is also a promising therapeutic agent for pancreatic cancer [85], cholangiocarcinoma [111] and colorectal cancer [112]. It is worth mentioning that many of the viral vectors developed to treat tumors have several common characteristics. Generally, VACV oncolytic vectors have a deletion in the TK gene, essential for the pyrimidine synthesis pathway, which forces the virus to replicate in cells displaying a high amount of nucleotide pools, enhancing the viral tropism to cancer cells. Others have a deletion in the VGF gene, preventing non-infected cells from proliferation [109]. Furthermore, as in the development of vaccines, viral vectors are "armed" with genes that enhance the antitumor activity, the virus tropism or the immunoreactivity, to promote better tumor destruction, such as granulocyte-macrophage colony-stimulating factor (GM-CSF) or erythropoietin genes (enhanced virus; Table 3). Another particular feature is that many of these recombinants carry reporter genes, and thus viral replication can be monitored by non-invasive imaging methods $[68,69,76,113]$. 
Table 3. Oncolytic vaccinia virus (VACV) developed for cancer treatment.

\begin{tabular}{|c|c|c|c|c|}
\hline \multirow{2}{*}{ Virus } & \multirow{2}{*}{ Target Cancer } & \multicolumn{2}{|c|}{ Features } & \multirow{2}{*}{ Reference } \\
\hline & & Inactive Genes & Additional Genes & \\
\hline \multicolumn{5}{|c|}{ Initial virus } \\
\hline JX-594 & $\begin{array}{l}\text { Melanoma, hepatocellular } \\
\text { carcinoma, colorectal } \\
\text { cancer }\end{array}$ & TK inactive, & LacZ and GM-CSF & {$[112,114]$} \\
\hline GLV-1h68 & $\begin{array}{l}\text { Colorectal cancer, prostate } \\
\text { cancer, salivary gland } \\
\text { carcinoma }\end{array}$ & $\begin{array}{c}\text { TK, } H A \text { and } F 14.5 L \\
\text { inactive }\end{array}$ & GFP, LacZ and GUS & [111] \\
\hline vvDD & Sarcomas, neuroblastoma & $T K$ and $V G F$ inactive & $C D$ & {$[115,116]$} \\
\hline \multicolumn{5}{|c|}{ Enhanced virus } \\
\hline GLV-1h153 & Pancreatic cancer & \multicolumn{2}{|c|}{ GLV-1h68 expressing $h N I S$} & [110] \\
\hline GLV-1h210 & Lung cancer & \multicolumn{2}{|c|}{ GLV-1h68 expressing $h E P O$} & [117] \\
\hline vvDD-SR-RFP & Sarcomas, neuroblastoma & $T K$ and $V G F$ inactive & $C D, R F P, S R$ & [118] \\
\hline
\end{tabular}

\section{Limitations of VACV Vectors}

The main limitation of using VACV as a vector is the short-term gene expression, since it is a lytic virus killing the infected cells. Thus, gene expression will not last for more than 12-24 h post-infection $[13,109]$. Additionally, although for some applications it is an advantage, since VACV replicates completely in the infected cell cytoplasm, it is hard to use VACV to engineer nuclear gene replacement [23]. The other main disadvantage is the limited immunogenicity in individuals vaccinated against smallpox. This pre-existing immunity reduces the effectiveness of vaccines based on VACV, although some trials have overcome this problem by mucosal vaccination with vaccinia vectors [5]. The VACV safety profile should be considered because it has progressive complications especially with immunocompromised individuals [11]. These limitations primarily affect in vivo applications of VACV recombinants in vaccine development, so several attenuated strains of VACV are being generated [9].

\section{New Perspectives}

As for other viruses, the development of vaccines or oncolytic therapies based on VACV requires the understanding of its pathogenesis and biology. Despite improvements in the vectors' design, such as the use of different promoters or insertion sites, homologous recombination has been almost exclusively the way to obtain VACV recombinants [45]. Homologous recombination requires the use of markers or reporter genes for selecting recombinants, which offers many disadvantages. Apart from the physical space needed for the marker gene, which is limited in therapeutic virus, the use of certain markers can introduce mutations or generate artifacts that are only found after an analysis of the generated virus. Sometimes, these problems cannot be detected in vitro, but are very important to overcome when these vectors are used in vivo on animal models $[46,48]$.

In recent years, some strategies have been developed to avoid these risks using markers, or at least to remove them from the final recombinant VACV. Rice and colleagues [45] described a double selection method to improve the selection of recombinant VACV, so that a reporter or marker gene is not necessary. A helper virus is used to rescue a recombinant VACV and is subsequently grown in non-permissive cells to the helper virus; allowing the selection of a large percentage of recombinant virions. However, the method that has certainly had an enormous importance in the modification of genomes is the clustered regularly interspaced short palindromic repeats (CRISPR)/CRISPR-associated protein 9 (Cas9) system. Briefly, the CRISPR/Cas9 system consists of an endonuclease (Cas9) employing a guide RNA to generate a break in a target place of the genome, later to be repaired, either randomly or precisely using a specifically designed "restful" template [119]. The effectiveness of this system has been proven in different organisms, including viruses, such as herpes simplex virus (HSV) [120], hepatitis B virus (HBV) [121] and HIV [76]. Currently, this technique is starting to be used also in 
VACV [47]. For example, this system has achieved the deletion of VACV virulence genes, such as $A 46 \mathrm{~L}$ and N1L. A46L and N1L are VACV intracellular proteins that inhibit nuclear factor-kappa B (NF-kB) activation, so it is undesirable that they were present in VACV vectors with therapeutic purposes [78]. Furthermore, given the efficiency of the method, "reparative" vectors with excisable marker genes have been designed. Therefore, recombinant viruses are effectively isolated, but eventually, the marker gene is eliminated [46]. Given the simplicity of recombinant VACV by the CRISPR/Cas9 system generation, an exponential increase of applications with better markers for basic research or without selectable markers for clinical application is expected $[119,120]$.

\section{Concluding Remarks}

In conclusion, the development of recombinant viruses is a promising therapeutic advance in the biomedical field. In this sense, the use of reporter-expressing VACVs has become a fundamental tool for a number of applications, in basic research, vaccine design and cancer therapy. As many of these trials are still experimental, more information is required regarding the side effects of the viral treatment. Continuing efforts are necessary to develop new reporter-expressing VACVs that are safer and more effective for future therapies.

Acknowledgments: We thank all of the pox virologist who contributed to this study. This work is supported by Grant FIS2011-00127 and Reference SAF2014-54623-R to SG.

Author Contributions: Sara Baldanta wrote the paper and created the figures, Saly al Ali and the rest of the authors also wrote the paper.

Conflicts of Interest: The authors declare no conflict of interest.

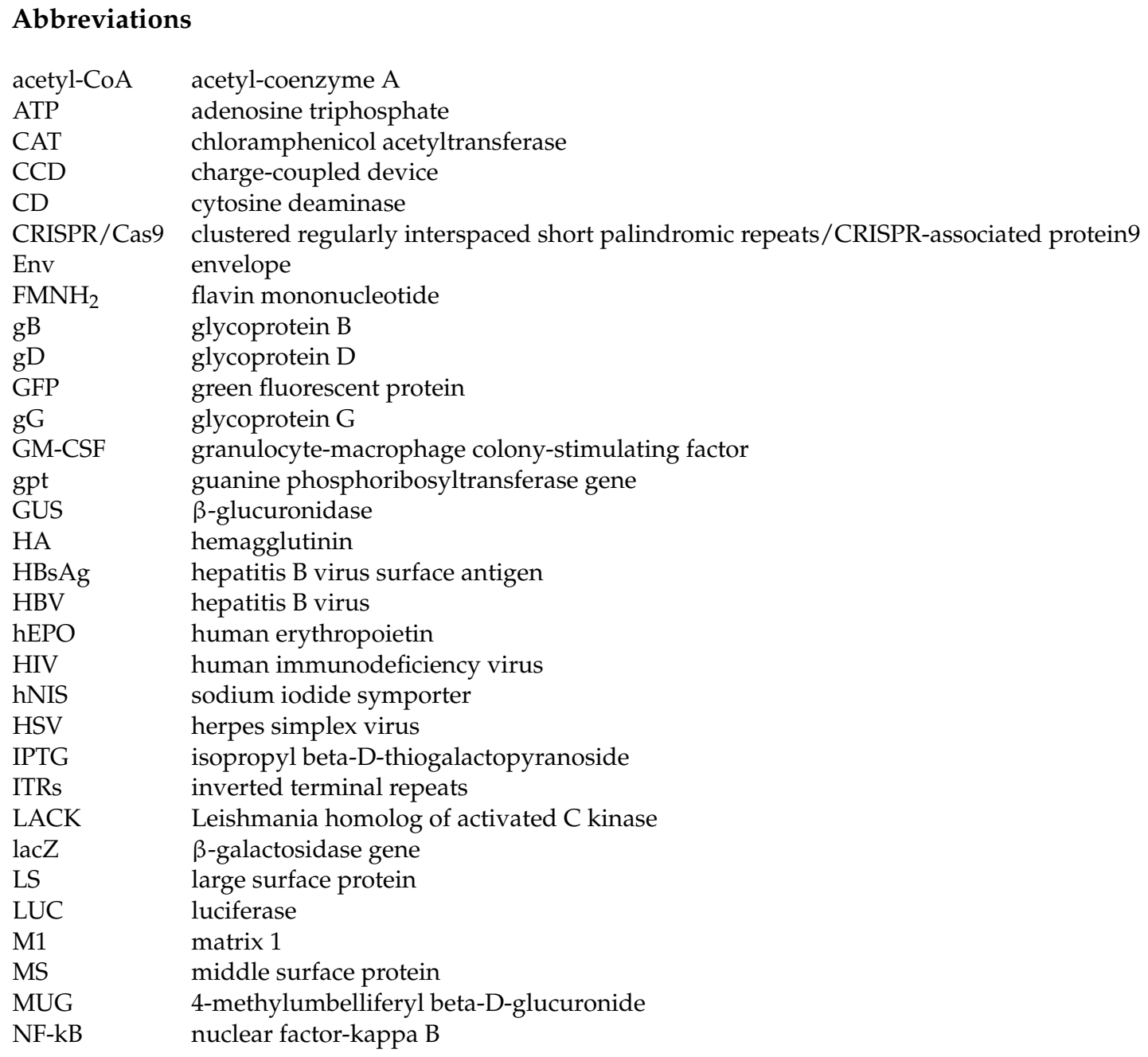




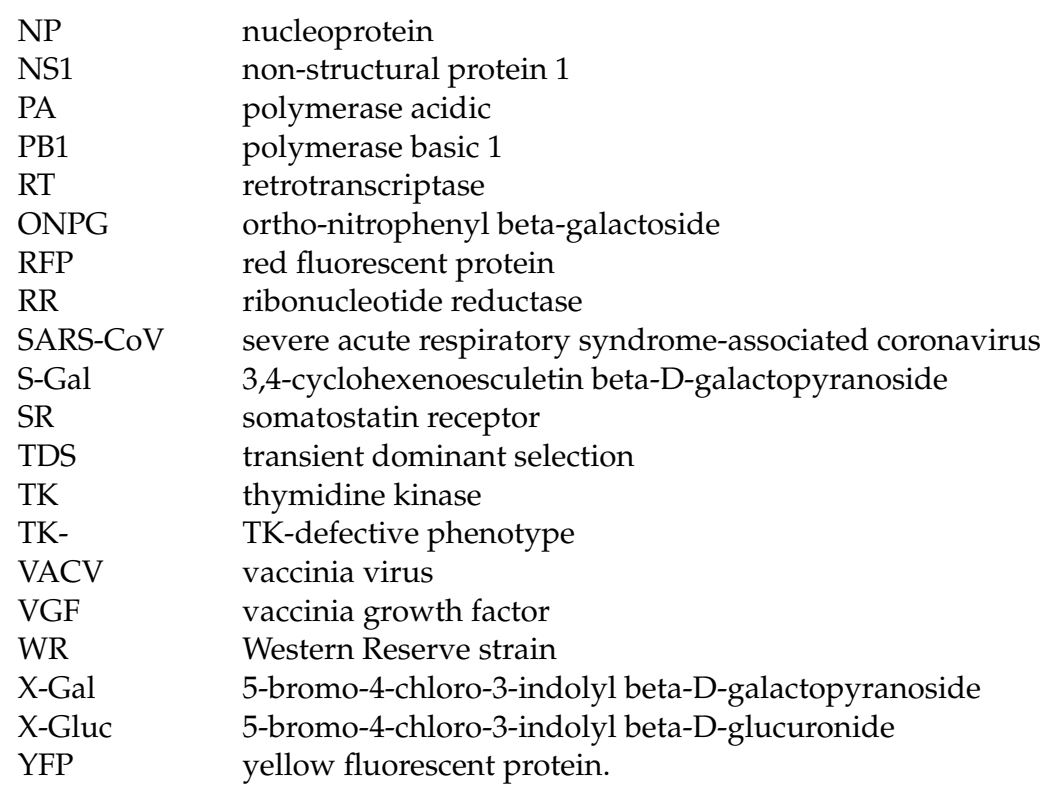

\section{References}

1. Wells, K.D. Genetic engineering of mammals. Cell. Tissue Res. 2016, 363, 289-294. [CrossRef] [PubMed]

2. Gill, S.S.; Gill, R.; Tuteja, R.; Tuteja, N. Genetic engineering of crops: A ray of hope for enhanced food security. Plant. Signal. Behav. 2014, 9, e28545. [CrossRef] [PubMed]

3. Van Pijkeren, J.P.; Britton, R.A. Precision genome engineering in lactic acid bacteria. Microb. Cell. Fact. 2014, 13, S10. [CrossRef] [PubMed]

4. Ura, T.; Okuda, K.; Shimada, M. Developments in viral vector-based vaccines. Vaccines 2014, 2, $624-641$. [CrossRef] [PubMed]

5. Souza, A.P.; Haut, L.; Reyes-Sandoval, A.; Pinto, A.R. Recombinant viruses as vaccines against viral diseases. Braz. J. Med. Biol. Res. 2005, 38, 509-522. [CrossRef] [PubMed]

6. Kim, T.K.; Eberwine, J.H. Mammalian cell transfection: The present and the future. Anal. Bioanal. Chem. 2010, 397, 3173-3178. [CrossRef] [PubMed]

7. Nakano, E.; Panicali, D.; Paoletti, E. Molecular genetics of vaccinia virus: Demonstration of marker rescue. Proc. Natl. Acad. Sci. USA 1982, 79, 1593-1596. [CrossRef] [PubMed]

8. Panicali, D.; Paoletti, E. Construction of poxviruses as cloning vectors: Insertion of the thymidine kinase gene from herpes simplex virus into the DNA of infectious vaccinia virus. Proc. Natl. Acad. Sci. USA 1982, 79, 4927-4931. [CrossRef] [PubMed]

9. Sanchez-Sampedro, L.; Perdiguero, B.; Mejias-Perez, E.; Garcia-Arriaza, J.; Di Pilato, M.; Esteban, M. The evolution of poxvirus vaccines. Viruses 2015, 7, 1726-1803. [CrossRef] [PubMed]

10. McFadden, G. Poxvirus tropism. Nat. Rev. Microbiol. 2005, 3, 201-213. [CrossRef] [PubMed]

11. Bhattacharya, S. The world health organization and global smallpox eradication. J. Epidemiol. Community Health 2008, 62, 909-912. [CrossRef] [PubMed]

12. Broyles, S.S. Vaccinia virus transcription. J. Gen. Virol. 2003, 84, 2293-2303. [CrossRef] [PubMed]

13. Hruby, D.E. Vaccinia virus vectors: New strategies for producing recombinant vaccines. Clin. Microbiol. Rev. 1990, 3, 153-170. [PubMed]

14. Hughes, A.L.; Friedman, R. Poxvirus genome evolution by gene gain and loss. Mol. Phylogenet. Evol. 2005, 35, 186-195. [CrossRef] [PubMed]

15. Moss, B. Poxvirus cell entry: How many proteins does it take? Viruses 2012, 4, 688-707. [CrossRef] [PubMed]

16. Schmidt, F.I.; Bleck, C.K.; Mercer, J. Poxvirus host cell entry. Curr. Opin. Virol. 2012, 2, 20-27. [CrossRef] [PubMed]

17. Rubins, K.H.; Hensley, L.E.; Bell, G.W.; Wang, C.; Lefkowitz, E.J.; Brown, P.O.; Relman, D.A. Comparative analysis of viral gene expression programs during poxvirus infection: A transcriptional map of the vaccinia and monkeypox genomes. PLoS ONE 2008, 3, e2628. [CrossRef] [PubMed] 
18. Roberts, K.L.; Smith, G.L. Vaccinia virus morphogenesis and dissemination. Trends Microbiol. 2008, 16, 472-479. [CrossRef] [PubMed]

19. Yen, J.; Golan, R.; Rubins, K. Vaccinia virus infection \& temporal analysis of virus gene expression: Part 1. J. Vis. Exp. 2009, 26, 1168.

20. Bleckwenn, N.A.; Bentley, W.E.; Shiloach, J. Exploring vaccinia virus as a tool for large-scale recombinant protein expression. Biotechnol. Prog. 2003, 19, 130-136. [CrossRef] [PubMed]

21. Bleckwenn, N.A.; Bentley, W.E.; Shiloach, J. Evaluation of production parameters with the vaccinia virus expression system using microcarrier attached HeLa cells. Biotechnol. Prog. 2005, 21, 554-561. [CrossRef] [PubMed]

22. Masternak, K.; Wittek, R. Cis- and trans-acting elements involved in reactivation of vaccinia virus early transcription. J. Virol. 1996, 70, 8737-8746. [PubMed]

23. Nascimento, I.P.; Leite, L.C. Recombinant vaccines and the development of new vaccine strategies. Braz. J. Med. Biol. Res. 2012, 45, 1102-1111. [CrossRef] [PubMed]

24. Bleckwenn, N.A.; Golding, H.; Bentley, W.E.; Shiloach, J. Production of recombinant proteins by vaccinia virus in a microcarrier based mammalian cell perfusion bioreactor. Biotechnol. Bioeng. 2005, 90, 663-674. [CrossRef] [PubMed]

25. Coupar, B.E.; Oke, P.G.; Andrew, M.E. Insertion sites for recombinant vaccinia virus construction: Effects on expression of a foreign protein. J. Gen. Virol. 2000, 81, 431-439. [CrossRef] [PubMed]

26. Kim, M. Replicating poxviruses for human cancer therapy. J. Microbiol. 2015, 53, 209-218. [CrossRef] [PubMed]

27. Garcel, A.; Fauquette, W.; Dehouck, M.P.; Crance, J.M.; Favier, A.L. Vaccinia virus-induced smallpox postvaccinal encephalitis in case of blood-brain barrier damage. Vaccine 2012, 30, 1397-1405. [CrossRef] [PubMed]

28. Henderson, D.A.; Moss, B. Recombinant vaccinia virus vaccines, 3rd ed.; Saunders: Philadelphia, 1999.

29. Moore, A.R.; Dong, B.; Chen, L.; Xiao, W. Vaccinia virus as a subhelper for AAV replication and packaging. Mol. Ther. Methods Clin. Dev. 2015, 2, 15044. [CrossRef] [PubMed]

30. Falkner, F.G.; Moss, B. Transient dominant selection of recombinant vaccinia viruses. J. Virol. 1990, 64, 3108-3111. [PubMed]

31. Falkner, F.G.; Moss, B. Escherichia coli gpt gene provides dominant selection for vaccinia virus open reading frame expression vectors. J. Virol. 1988, 62, 1849-1854. [PubMed]

32. Marzook, N.B.; Procter, D.J.; Lynn, H.; Yamamoto, Y.; Horsington, J.; Newsome, T.P. Methodology for the efficient generation of fluorescently tagged vaccinia virus proteins. J. Vis. Exp. 2014, e51151. [CrossRef] [PubMed]

33. Kochneva, G.; Zonov, E.; Grazhdantseva, A.; Yunusova, A.; Sibolobova, G.; Popov, E.; Taranov, O.; Netesov, S.; Chumakov, P.; Ryabchikova, E. Apoptin enhances the oncolytic properties of vaccinia virus and modifies mechanisms of tumor regression. Oncotarget 2014, 5, 11269-11282. [CrossRef] [PubMed]

34. Rodriguez, D.; Gonzalez-Aseguinolaza, G.; Rodriguez, J.R.; Vijayan, A.; Gherardi, M.; Rueda, P.; Casal, J.I.; Esteban, M. Vaccine efficacy against malaria by the combination of porcine parvovirus-like particles and vaccinia virus vectors expressing CS of Plasmodium. PLoS ONE 2012, 7, e34445. [CrossRef] [PubMed]

35. Gomez, C.E.; Rodriguez, D.; Rodriguez, J.R.; Abaitua, F.; Duarte, C.; Esteban, M. Enhanced CD8+ T cell immune response against a V3 loop multi-epitope polypeptide (TAB13) of HIV-1 Env after priming with purified fusion protein and booster with modified vaccinia virus ankara (MVA-TAB) recombinant: A comparison of humoral and cellular immune responses with the vaccinia virus western reserve (WR) vector. Vaccine 2001, 20, 961-971. [PubMed]

36. Brown, C.K.; Turner, P.C.; Moyer, R.W. Molecular characterization of the vaccinia virus hemagglutinin gene. J. Virol. 1991, 65, 3598-3606. [PubMed]

37. O'Brien, T.C.; Tauraso, N.M. Vaccinia virus: Kinetics of the hemagglutination-inhibition test and preparation of hemagglutinin. Arch. Gesamte. Virusforsch. 1972, 36, 158-165. [CrossRef] [PubMed]

38. Paoletti, E.; Lipinskas, B.R.; Samsonoff, C.; Mercer, S.; Panicali, D. Construction of live vaccines using genetically engineered poxviruses: Biological activity of vaccinia virus recombinants expressing the hepatitis B virus surface antigen and the herpes simplex virus glycoprotein D. Proc. Natl. Acad. Sci. USA 1984, 81, 193-197. [PubMed] 
39. Buller, R.M.; Chakrabarti, S.; Cooper, J.A.; Twardzik, D.R.; Moss, B. Deletion of the vaccinia virus growth factor gene reduces virus virulence. J. Virol. 1988, 62, 866-874. [PubMed]

40. Buller, R.M.; Smith, G.L.; Cremer, K.; Notkins, A.L.; Moss, B. Decreased virulence of recombinant vaccinia virus expression vectors is associated with a thymidine kinase-negative phenotype. Nature 1985, 317, 813-815. [CrossRef] [PubMed]

41. Child, S.J.; Palumbo, G.J.; Buller, R.M.; Hruby, D.E. Insertional inactivation of the large subunit of ribonucleotide reductase encoded by vaccinia virus is associated with reduced virulence in vivo. Virology 1990, 174, 625-629. [CrossRef]

42. Rodriguez, D.; Rodriguez, J.R.; Rodriguez, J.F.; Trauber, D.; Esteban, M. Highly attenuated vaccinia virus mutants for the generation of safe recombinant viruses. Proc. Natl. Acad. Sci. USA 1989, 86, 1287-1291. [CrossRef] [PubMed]

43. Condit, R.C.; Motyczka, A.; Spizz, G. Isolation, characterization, and physical mapping of temperature-sensitive mutants of vaccinia virus. Virology 1983, 128, 429-443. [CrossRef]

44. Jiang, T.; Xing, B.; Rao, J. Recent developments of biological reporter technology for detecting gene expression. Biotechnol. Genet. Eng. Rev. 2008, 25, 41-75. [CrossRef] [PubMed]

45. Rice, A.D.; Gray, S.A.; Li, Y.; Damon, I.; Moyer, R.W. An efficient method for generating poxvirus recombinants in the absence of selection. Viruses 2011, 3, 217-232. [CrossRef] [PubMed]

46. Yuan, M.; Gao, X.; Chard, L.S.; Ali, Z.; Ahmed, J.; Li, Y.; Liu, P.; Lemoine, N.R.; Wang, Y. A marker-free system for highly efficient construction of vaccinia virus vectors using CRISPR Cas9. Mol. Ther. Methods Clin. Dev. 2015, 2, 15035. [CrossRef] [PubMed]

47. Yuan, M.; Zhang, W.; Wang, J.; Al Yaghchi, C.; Ahmed, J.; Chard, L.; Lemoine, N.R.; Wang, Y. Efficiently editing the vaccinia virus genome by using the CRISPR-Cas9 system. J. Virol. 2015, 89, 5176-5179. [CrossRef] [PubMed]

48. Falzarano, D.; Groseth, A.; Hoenen, T. Development and application of reporter-expressing mononegaviruses: Current challenges and perspectives. Antiviral Res. 2014, 103, 78-87. [CrossRef] [PubMed]

49. Ghim, C.M.; Lee, S.K.; Takayama, S.; Mitchell, R.J. The art of reporter proteins in science: Past, present and future applications. BMB Rep. 2010, 43, 451-460. [CrossRef] [PubMed]

50. Swenson, E.S.; Price, J.G.; Brazelton, T.; Krause, D.S. Limitations of green fluorescent protein as a cell lineage marker. Stem Cells 2007, 25, 2593-2600. [CrossRef] [PubMed]

51. Gorman, C.M.; Moffat, L.F.; Howard, B.H. Recombinant genomes which express chloramphenicol acetyltransferase in mammalian cells. Mol. Cell. Biol. 1982, 2, 1044-1051. [CrossRef] [PubMed]

52. Overbeek, P.A.; Lai, S.P.; Van Quill, K.R.; Westphal, H. Tissue-specific expression in transgenic mice of a fused gene containing RSV terminal sequences. Science 1986, 231, 1574-1577. [CrossRef] [PubMed]

53. Juers, D.H.; Matthews, B.W.; Huber, R.E. LacZ beta-galactosidase: Structure and function of an enzyme of historical and molecular biological importance. Protein Sci. 2012, 21, 1792-1807. [CrossRef] [PubMed]

54. Carroll, M.W.; Moss, B. E. coli beta-glucuronidase (GUS) as a marker for recombinant vaccinia viruses. BioTechniques 1995, 19, 352-354, 356. [PubMed]

55. Bleckwenn, N.A.; Bentley, W.E.; Shiloach, J. Vaccinia virus-based expression of gp120 and eGFP: Survey of mammalian host cell lines. Biotechnol. Prog. 2005, 21, 186-191. [CrossRef] [PubMed]

56. Gahan, C.G. The bacterial lux reporter system: Applications in bacterial localisation studies. Curr. Gene Ther. 2012, 12, 12-19. [CrossRef] [PubMed]

57. Gould, S.J.; Subramani, S. Firefly luciferase as a tool in molecular and cell biology. Anal. Biochem. 1988, 175, 5-13. [CrossRef]

58. Kirby, J.; Heath, P.R.; Shaw, P.J.; Hamdy, F.C. Gene expression assays. Adv. Clin. Chem. 2007, 44, $247-292$. [PubMed]

59. Cui, W.; Liu, L.; Kodibagkar, V.D.; Mason, R.P. S-Gal, a novel 1h MRI reporter for beta-galactosidase. Magn. Reson. Med. 2010, 64, 65-71. [CrossRef] [PubMed]

60. Chakrabarti, S.; Brechling, K.; Moss, B. Vaccinia virus expression vector: Coexpression of beta-galactosidase provides visual screening of recombinant virus plaques. Mol. Cell. Biol. 1985, 5, 3403-3409. [PubMed]

61. Villari, P.; Iannuzzo, M.; Torre, I. An evaluation of the use of 4-methylumbelliferyl-beta-d-glucuronide (MUG) in different solid media for the detection and enumeration of escherichia coli in foods. Lett. Appl. Microbiol. 1997, 24, 286-290. [CrossRef] 
62. Howley, P.M.; Spehner, D.; Drillien, R. A vaccinia virus transfer vector using a GUS reporter gene inserted into the I4L locus. Gene 1996, 172, 233-237. [CrossRef]

63. Dvoracek, B.; Shors, T. Construction of a novel set of transfer vectors to study vaccinia virus replication and foreign gene expression. Plasmid 2003, 49, 9-17. [CrossRef]

64. Tsuji, F.I. Early history, discovery, and expression of aequorea green fluorescent protein, with a note on an unfinished experiment. Microsc. Res. Tech. 2010, 73, 785-796. [PubMed]

65. The Nobel Prize in Chemistry 2008. Available online: http://www.nobelprize.org/nobel_prizes/chemistry/ laureates/2008/ (accessed on 19 May 2016).

66. Coralli, C.; Cemazar, M.; Kanthou, C.; Tozer, G.M.; Dachs, G.U. Limitations of the reporter green fluorescent protein under simulated tumor conditions. Cancer Res. 2001, 61, 4784-4790. [PubMed]

67. Prescher, J.A.; Contag, C.H. Guided by the light: Visualizing biomolecular processes in living animals with bioluminescence. Curr. Opin. Chem. Biol. 2010, 14, 80-89. [CrossRef] [PubMed]

68. Zhu, R.; Liu, Q.; Huang, W.; Yu, Y.; Wang, Y. Comparison of the replication characteristics of vaccinia virus strains Guang 9 and Tian Tan in vivo and in vitro. Arch. Virol. 2014, 159, 2587-2596. [CrossRef] [PubMed]

69. Zaitseva, M.; Kapnick, S.M.; Meseda, C.A.; Shotwell, E.; King, L.R.; Manischewitz, J.; Scott, J.; Kodihalli, S.; Merchlinsky, M.; Nielsen, H.; et al. Passive immunotherapies protect WRvFire and IHD-J-Luc vaccinia virus-infected mice from lethality by reducing viral loads in the upper respiratory tract and internal organs. J. Virol. 2011, 85, 9147-9158. [CrossRef] [PubMed]

70. Tsoneva, D.; Stritzker, J.; Bedenk, K.; Zhang, Q.; Frentzen, A.; Cappello, J.; Fischer, U.; Szalay, A.A. Drug-encoded biomarkers for monitoring biological therapies. PLoS ONE 2015, 10, e0137573. [CrossRef] [PubMed]

71. Manischewitz, J.; King, L.R.; Bleckwenn, N.A.; Shiloach, J.; Taffs, R.; Merchlinsky, M.; Eller, N.; Mikolajczyk, M.G.; Clanton, D.J.; Monath, T.; et al. Development of a novel vaccinia-neutralization assay based on reporter-gene expression. J. Infect. Dis. 2003, 188, 440-448. [CrossRef] [PubMed]

72. Li, Y.; Sheng, Y.; Chu, Y.; Ji, H.; Jiang, S.; Lan, T.; Li, M.; Chen, S.; Fan, Y.; Li, W.; et al. Seven major genomic deletions of vaccinia virus Tiantan strain are sufficient to decrease pathogenicity. Antiviral Res. 2016, 129, 1-12. [CrossRef] [PubMed]

73. Turner, P.C.; Moyer, R.W. The vaccinia virus fusion inhibitor proteins SPI-3 (K2) and HA (A56) expressed by infected cells reduce the entry of superinfecting virus. Virology 2008, 380, 226-233. [CrossRef] [PubMed]

74. Ward, B.M. Visualization and characterization of the intracellular movement of vaccinia virus intracellular mature virions. J. Virol. 2005, 79, 4755-4763. [CrossRef] [PubMed]

75. Warren, R.D.; Cotter, C.A.; Moss, B. Reverse genetics analysis of poxvirus intermediate transcription factors. J. Virol. 2012, 86, 9514-9519. [CrossRef] [PubMed]

76. Zhu, W.; Lei, R.; Le Duff, Y.; Li, J.; Guo, F.; Wainberg, M.A.; Liang, C. The CRISPR/Cas9 system inactivates latent HIV-1 proviral DNA. Retrovirology 2015, 12, 22. [CrossRef] [PubMed]

77. Chan, W.M.; Ward, B.M. The A33-dependent incorporation of B5 into extracellular enveloped vaccinia virions is mediated through an interaction between their lumenal domains. J. Virol. 2012, 86, 8210-8220. [CrossRef] [PubMed]

78. Smith, G.L.; Benfield, C.T.; Maluquer de Motes, C.; Mazzon, M.; Ember, S.W.; Ferguson, B.J.; Sumner, R.P. Vaccinia virus immune evasion: Mechanisms, virulence and immunogenicity. J. Gen. Virol. 2013, 94, 2367-2392. [CrossRef] [PubMed]

79. Unterholzner, L.; Sumner, R.P.; Baran, M.; Ren, H.; Mansur, D.S.; Bourke, N.M.; Randow, F.; Smith, G.L.; Bowie, A.G. Vaccinia virus protein C6 is a virulence factor that binds tbk-1 adaptor proteins and inhibits activation of IRF3 and IRF7. PLoS Pathog. 2011, 7, e1002247. [CrossRef] [PubMed]

80. Johnson, M.C.; Damon, I.K.; Karem, K.L. A rapid, high-throughput vaccinia virus neutralization assay for testing smallpox vaccine efficacy based on detection of green fluorescent protein. J. Virol. Methods 2008, 150, 14-20. [CrossRef] [PubMed]

81. Wang, W.; Li, R.; Deng, Y.; Lu, N.; Chen, H.; Meng, X.; Wang, W.; Wang, X.; Yan, K.; Qi, X.; et al. Protective efficacy of the conserved NP, PB1, and M1 proteins as immunogens in DNA- and vaccinia virus-based universal influenza a virus vaccines in mice. Clin. Vaccine Immunol. 2015, 22, 618-630. [CrossRef] [PubMed]

82. Van den Worm, S.H.; Eriksson, K.K.; Zevenhoven, J.C.; Weber, F.; Zust, R.; Kuri, T.; Dijkman, R.; Chang, G.; Siddell, S.G.; Snijder, E.J.; et al. Reverse genetics of SARS-related coronavirus using vaccinia virus-based recombination. PLoS ONE 2012, 7, e32857. [CrossRef] [PubMed] 
83. Harrington, L.E.; Most Rv, R.; Whitton, J.L.; Ahmed, R. Recombinant vaccinia virus-induced T-cell immunity: Quantitation of the response to the virus vector and the foreign epitope. J. Virol. 2002, 76, 3329-3337. [CrossRef] [PubMed]

84. Qiu, S.; Ren, X.; Ben, Y.; Ren, Y.; Wang, J.; Zhang, X.; Wan, Y.; Xu, J. Fusion-expressed ctb improves both systemic and mucosal T-cell responses elicited by an intranasal DNA priming/intramuscular recombinant vaccinia boosting regimen. J. Immunol. Res. 2014, 2014, 308732. [CrossRef] [PubMed]

85. Yaghchi, C.A.; Zhang, Z.; Alusi, G.; Lemoine, N.R.; Wang, Y. Vaccinia virus, a promising new therapeutic agent for pancreatic cancer. Immunotherapy 2015, 7, 1249-1258. [CrossRef] [PubMed]

86. Vemulapalli, R.; Cravero, S.; Calvert, C.L.; Toth, T.E.; Sriranganathan, N.; Boyle, S.M.; Rossetti, O.L.; Schurig, G.G. Characterization of specific immune responses of mice inoculated with recombinant vaccinia virus expressing an 18-kilodalton outer membrane protein of brucella abortus. Clin. Diagn. Lab. Immunol. 2000, 7, 114-118. [CrossRef] [PubMed]

87. Langford, C.J.; Edwards, S.J.; Smith, G.L.; Mitchell, G.F.; Moss, B.; Kemp, D.J.; Anders, R.F. Anchoring a secreted plasmodium antigen on the surface of recombinant vaccinia virus-infected cells increases its immunogenicity. Mol. Cell. Biol. 1986, 6, 3191-3199. [CrossRef] [PubMed]

88. Smith, G.L.; Godson, G.N.; Nussenzweig, V.; Nussenzweig, R.S.; Barnwell, J.; Moss, B. Plasmodium knowlesi sporozoite antigen: Expression by infectious recombinant vaccinia virus. Science 1984, 224, 397-399. [CrossRef] [PubMed]

89. Gherardi, M.M.; Ramirez, J.C.; Rodriguez, D.; Rodriguez, J.R.; Sano, G.; Zavala, F.; Esteban, M. IL-12 delivery from recombinant vaccinia virus attenuates the vector and enhances the cellular immune response against HIV-1 Env in a dose-dependent manner. J. Immunol. 1999, 162, 6724-6733. [PubMed]

90. Valkenburg, S.A.; Li, O.T.; Mak, P.W.; Mok, C.K.; Nicholls, J.M.; Guan, Y.; Waldmann, T.A.; Peiris, J.S.; Perera, L.P.; Poon, L.L. IL-15 adjuvanted multivalent vaccinia-based universal influenza vaccine requires CD4+ T cells for heterosubtypic protection. Proc. Natl. Acad. Sci. USA 2014, 111, 5676-5681. [CrossRef] [PubMed]

91. Brochier, B.; Aubert, M.F.; Pastoret, P.P.; Masson, E.; Schon, J.; Lombard, M.; Chappuis, G.; Languet, B.; Desmettre, P. Field use of a vaccinia-rabies recombinant vaccine for the control of sylvatic rabies in europe and North America. Rev. Sci. Tech. 1996, 15, 947-970. [CrossRef] [PubMed]

92. Gherardi, M.M.; Najera, J.L.; Perez-Jimenez, E.; Guerra, S.; Garcia-Sastre, A.; Esteban, M. Prime-boost immunization schedules based on influenza virus and vaccinia virus vectors potentiate cellular immune responses against human immunodeficiency virus Env protein systemically and in the genitorectal draining lymph nodes. J. Virol. 2003, 77, 7048-7057. [CrossRef] [PubMed]

93. Walker, B.D.; Flexner, C.; Paradis, T.J.; Fuller, T.C.; Hirsch, M.S.; Schooley, R.T.; Moss, B. HIV-1 reverse transcriptase is a target for cytotoxic T lymphocytes in infected individuals. Science 1988, 240, 64-66. [CrossRef] [PubMed]

94. Cheliapov, N.V.; Chernos, V.I.; Andzhaparidze, O.G. Analysis of antibody formation to the vaccinia virus in human subjects and rabbits in response to the administration of a recombinant vaccinia-hepatitis $B$ vaccine. Vopr. Virusol. 1988, 33, 175-179. [PubMed]

95. Grigorieva, I.M.; Grigoriev, V.G.; Zakharova, L.G.; Pashvykina, G.V.; Shevlyagin, V.Y.; Altstein, A.D. Immunogenicity of recombinant vaccinia viruses expressing hepatitis B virus surface antigen in mice. Immunol. Lett. 1993, 36, 267-271. [CrossRef]

96. Kutinova, L.; Ludvikova, V.; Krystofova, J.; Otavova, M.; Simonova, V.; Nemeckova, S.; Hainz, P.; Vonka, V. Influence of the parental virus strain on the virulence and immunogenicity of recombinant vaccinia viruses expressing HBV Pres2-S protein or VZV glycoprotein I. Vaccine 1996, 14, 1045-1052. [CrossRef]

97. Cheng, K.C.; Smith, G.L.; Moss, B. Hepatitis B virus large surface protein is not secreted but is immunogenic when selectively expressed by recombinant vaccinia virus. J. Virol. 1986, 60, 337-344. [PubMed]

98. Cheng, K.C.; Moss, B. Selective synthesis and secretion of particles composed of the hepatitis B virus middle surface protein directed by a recombinant vaccinia virus: Induction of antibodies to pre-S and S epitopes. J. Virol. 1987, 61, 1286-1290. [PubMed]

99. Rooney, J.F.; Wohlenberg, C.; Cremer, K.J.; Moss, B.; Notkins, A.L. Immunization with a vaccinia virus recombinant expressing herpes simplex virus type 1 glycoprotein $D$ : Long-term protection and effect of revaccination. J. Virol. 1988, 62, 1530-1534. [PubMed] 
100. Martin, S.; Moss, B.; Berman, P.W.; Laskey, L.A.; Rouse, B.T. Mechanisms of antiviral immunity induced by a vaccinia virus recombinant expressing herpes simplex virus type 1 glycoprotein D: Cytotoxic t cells. J. Virol. 1987, 61, 726-734. [PubMed]

101. Cantin, E.M.; Eberle, R.; Baldick, J.L.; Moss, B.; Willey, D.E.; Notkins, A.L.; Openshaw, H. Expression of herpes simplex virus 1 glycoprotein $B$ by a recombinant vaccinia virus and protection of mice against lethal herpes simplex virus 1 infection. Proc. Natl. Acad. Sci. USA 1987, 84, 5908-5912. [CrossRef] [PubMed]

102. McLaughlin-Taylor, E.; Willey, D.E.; Cantin, E.M.; Eberle, R.; Moss, B.; Openshaw, H. A recombinant vaccinia virus expressing herpes simplex virus type 1 glycoprotein B induces cytotoxic T lymphocytes in mice. J. Gen. Virol. 1988, 69(Pt. 7), 1731-1734. [CrossRef] [PubMed]

103. Sullivan, V.; Smith, G.L. Expression and characterization of herpes simplex virus type 1 (HSV-1) glycoprotein $\mathrm{G}(\mathrm{gG})$ by recombinant vaccinia virus: Neutralization of HSV-1 infectivity with anti-gG antibody. J. Gen. Virol. 1987, 68(Pt. 10), 2587-2598. [CrossRef] [PubMed]

104. Smith, G.L.; Murphy, B.R.; Moss, B. Construction and characterization of an infectious vaccinia virus recombinant that expresses the influenza hemagglutinin gene and induces resistance to influenza virus infection in hamsters. Proc. Natl. Acad. Sci. USA 1983, 80, 7155-7159. [CrossRef] [PubMed]

105. Goodman, A.G.; Heinen, P.P.; Guerra, S.; Vijayan, A.; Sorzano, C.O.; Gomez, C.E.; Esteban, M. A human multi-epitope recombinant vaccinia virus as a universal $\mathrm{T}$ cell vaccine candidate against influenza virus. PLoS ONE 2011, 6, e25938. [CrossRef] [PubMed]

106. Ramos, I.; Alonso, A.; Marcen, J.M.; Peris, A.; Castillo, J.A.; Colmenares, M.; Larraga, V. Heterologous prime-boost vaccination with a non-replicative vaccinia recombinant vector expressing lack confers protection against canine visceral leishmaniasis with a predominant Th1-specific immune response. Vaccine 2008, 26, 333-344. [CrossRef] [PubMed]

107. Cross, M.L.; Fleming, S.B.; Cowan, P.E.; Scobie, S.; Whelan, E.; Prada, D.; Mercer, A.A.; Duckworth, J.A. Vaccinia virus as a vaccine delivery system for marsupial wildlife. Vaccine 2011, 29, 4537-4543. [CrossRef] [PubMed]

108. Hruby, D.E.; Hodges, W.M.; Wilson, E.M.; Franke, C.A.; Fischetti, V.A. Expression of streptococcal M protein in mammalian cells. Proc. Natl. Acad. Sci. USA 1988, 85, 5714-5717. [CrossRef] [PubMed]

109. Chan, W.M.; McFadden, G. Oncolytic poxviruses. Annu. Rev. Virol. 2014, 1, 119-141. [CrossRef] [PubMed]

110. Mansfield, D.C.; Kyula, J.N.; Rosenfelder, N.; Chao-Chu, J.; Kramer-Marek, G.; Khan, A.A.; Roulstone, V.; McLaughlin, M.; Melcher, A.A.; Vile, R.G.; et al. Oncolytic vaccinia virus as a vector for therapeutic sodium iodide symporter gene therapy in prostate cancer. Gene Ther. 2016, 23, 357-368. [CrossRef] [PubMed]

111. Pugalenthi, A.; Mojica, K.; Ady, J.W.; Johnsen, C.; Love, D.; Chen, N.G.; Aguilar, R.J.; Szalay, A.A.; Fong, Y. Recombinant vaccinia virus GLV-1h68 is a promising oncolytic vector in the treatment of cholangiocarcinoma. Cancer Gene Ther. 2015, 22, 591-596. [CrossRef] [PubMed]

112. Park, S.H.; Breitbach, C.J.; Lee, J.; Park, J.O.; Lim, H.Y.; Kang, W.K.; Moon, A.; Mun, J.H.; Sommermann, E.M.; Maruri Avidal, L.; et al. Phase 1b trial of biweekly intravenous Pexa-Vec (JX-594), an oncolytic and immunotherapeutic vaccinia virus in colorectal cancer. Mol. Ther. 2015, 23, 1532-1540. [CrossRef] [PubMed]

113. Bauzon, M.; Hermiston, T. Armed therapeutic viruses - a disruptive therapy on the horizon of cancer immunotherapy. Front. Immunol. 2014, 5, 74. [CrossRef] [PubMed]

114. Merrick, A.E.; Ilett, E.J.; Melcher, A.A. Jx-594, a targeted oncolytic poxvirus for the treatment of cancer. Curr. Opin. Investig. Drugs. 2009, 10, 1372-1382. [PubMed]

115. McCart, J.A.; Ward, J.M.; Lee, J.; Hu, Y.; Alexander, H.R.; Libutti, S.K.; Moss, B.; Bartlett, D.L. Systemic cancer therapy with a tumor-selective vaccinia virus mutant lacking thymidine kinase and vaccinia growth factor genes. Cancer Res. 2001, 61, 8751-8757. [PubMed]

116. Lun, X.; Ruan, Y.; Jayanthan, A.; Liu, D.J.; Singh, A.; Trippett, T.; Bell, J.; Forsyth, P.; Johnston, R.N.; Narendran, A. Double-deleted vaccinia virus in virotherapy for refractory and metastatic pediatric solid tumors. Mol. Oncol. 2013, 7, 944-954. [CrossRef] [PubMed]

117. Nguyen, D.H.; Chen, N.G.; Zhang, Q.; Le, H.T.; Aguilar, R.J.; Yu, Y.A.; Cappello, J.; Szalay, A.A. Vaccinia virus-mediated expression of human erythropoietin in tumors enhances virotherapy and alleviates cancer-related anemia in mice. Mol. Ther. 2013, 21, 2054-2062. [CrossRef] [PubMed]

118. McCart, J.A.; Mehta, N.; Scollard, D.; Reilly, R.M.; Carrasquillo, J.A.; Tang, N.; Deng, H.; Miller, M.; Xu, H.; Libutti, S.K.; et al. Oncolytic vaccinia virus expressing the human somatostatin receptor SSTR2: Molecular imaging after systemic delivery using 111in-pentetreotide. Mol. Ther. 2004, 10, 553-561. [PubMed] 
119. Mei, Y.; Wang, Y.; Chen, H.; Sun, Z.S.; Ju, X.D. Recent progress in CRISPR/Cas9 technology. J. Genet. Genomics. 2016, 43, 63-75. [CrossRef] [PubMed]

120. Suenaga, T.; Kohyama, M.; Hirayasu, K.; Arase, H. Engineering large viral DNA genomes using the CRISPR-Cas9 system. Microbiol. Immunol. 2014, 58, 513-522. [CrossRef] [PubMed]

121. Lin, G.; Zhang, K.; Li, J. Application of CRISPR/Cas9 technology to HBV. Int. J. Mol. Sci. 2015, 16, 26077-26086. [CrossRef] [PubMed]

(c)

(C) 2016 by the authors; licensee MDPI, Basel, Switzerland. This article is an open access article distributed under the terms and conditions of the Creative Commons Attribution (CC-BY) license (http://creativecommons.org/licenses/by/4.0/). 